\title{
Effect of abomasal infusions of a mixture of octadecenoic acids on milk fat synthesis in lactating cows ${ }^{1}$
}

\author{
K. J. Shingfield,,$^{2}$ A. Sæbø, $\dagger^{3}$ P.-C. Sæbø, $\dagger$ V. Toivonen, ${ }^{*}$ and J. M. Griinarił \\ ${ }^{*}$ Animal Production Research, MTT Agrifood Research Finland, FI-31600, Jokioinen, Finland \\ †Natural ASA, N-6160, Hovdebygda, Norway \\ †Department of Animal Science, University of Helsinki, FI-00014, Helsinki, Finland
}

\section{ABSTRACT}

Diets causing milk fat depression (MFD) are known to alter ruminal lipid metabolism leading to the formation of specific biohydrogenation intermediates that exert antilipogenic effects. Several isomers of conjugated linoleic acid (CLA), namely trans-10, cis-12 CLA, cis-10, trans-12 CLA, and trans-9, cis-11 CLA, inhibit mammary lipogenesis in the lactating cow, but ruminal outflow of these biohydrogenation intermediates does not account entirely for the reductions in milk fat synthesis during diet-induced MFD. Milk fat trans-10 18:1 concentrations are consistently increased on diets that cause MFD, suggesting a possible role in the regulation of milk fat secretion. Three rumenfistulated cows in mid lactation were used in a $3 \times 3$ Latin square to evaluate the effects of a mixture of 18:1 fatty acid methyl esters (FAME) on milk fat synthesis. Experimental treatments consisted of abomasal infusions of ethanol (control), $6 \mathrm{~g} / \mathrm{d}$ of trans-10, cis-12 CLA (positive control; CLA), or $247 \mathrm{~g} / \mathrm{d}$ of a mixture of 18:1 FAME containing (\% fatty acids) cis-9 (9.45), cis-12 (3.35), trans-10 (37.3), trans-11 (37.4), and trans-12 (2.66) as major isomers (T181 treatment). Administration of the T181 treatment supplied $92.1 \mathrm{~g} / \mathrm{d}$ of trans- 10 18:1. Infusions were conducted over a 5 -d period with a 9-d interval between treatments. Treatments had no effect on dry matter intake, milk yield, or milk protein. Relative to the control, abomasal infusion of T181 and trans-10, cis-12 CLA treatments reduced milk fat secretion by 19.5 and $41.5 \%$, respectively. Even though a direct cause and effect on mammary lipogenesis could not be established, comparisons with published data and considerations of the relative abundance of constituent FAME in treatment T181 implicated trans-10

Received December 28, 2008.

Accepted May 19, 2009.

${ }^{1}$ Supported in part by the Finnish Ministry of Agriculture and Forestry.

${ }^{2}$ Corresponding author: kevin.shingfield@mtt.fi

${ }^{3}$ Current address: Pharma Marine AS, LKG Biotech Park, Terøy, 6280 Søvik, Norway.
18:1 as the isomer responsible. In conclusion, current data suggest that trans-10 18:1 potentially exerts antilipogenic effects and may contribute to the reduction in milk fat synthesis during diet-induced MFD in the lactating cow.

Key words: milk fat, trans fatty acid, conjugated linoleic acid, lactation

\section{INTRODUCTION}

Fat is the major energy constituent in milk and is an important component contributing to the processing attributes, physical characteristics, and organoleptic properties of ruminant milk and dairy products (Palmquist et al., 1993; Chilliard and Ferlay, 2004). Milk fat content is influenced by several genetic and physiological factors. Although animal selection and improvements in genetic merit can be used to effect long-term changes in milk fat content, nutrition is the major environmental factor regulating milk fat synthesis (Lock and Shingfield, 2004). Concentrations of milk fat are reduced in response to low-fiber, high-concentrate diets or to supplements of plant oils or marine lipids (Bauman and Griinari, 2003; Shingfield and Griinari, 2007). Diets that cause milk fat depression (MFD) also induce changes in milk fatty acid composition characterized by an overall increase in trans fatty acid concentrations (Davis and Brown, 1970) and specific changes in the distribution of 18:1 isomers (Griinari et al., 1998; Piperova et al., 2000, 2002). Several theories have been proposed to explain the causes of diet-induced MFD (Bauman and Griinari, 2001, 2003). Based on the associated changes in milk fat composition during MFD, Bauman and Griinari (2001) proposed the biohydrogenation theory, which states that diets causing MFD also alter ruminal lipid metabolism resulting in the formation of specific biohydrogenation intermediates that directly inhibit milk fat synthesis.

Postruminal infusion studies have established that trans-10, cis-12 conjugated linoleic acid (CLA) formed during ruminal 18:2n-6 metabolism (Griinari and Bauman, 1999; Palmquist et al., 2005) inhibits milk fat 
synthesis in the lactating cow (Baumgard et al., 2000, 2001; Peterson et al., 2002). More recent studies have provided further evidence that cis-10, trans-12 CLA (Sæbø et al., 2005) and trans-9, cis-11 CLA (Perfield et al., 2007), which are ruminal biohydrogenation intermediates of 18:2n-6 (Wallace et al., 2007), also exert antilipogenic effects. However, the increases in ruminal outflow of biohydrogenation intermediates known to inhibit milk fat synthesis do not explain entirely dietinduced MFD, with the implication that additional biohydrogenation intermediates or other mechanisms are also involved (Shingfield and Griinari, 2007).

Diets causing MFD modify ruminal lipid metabolism resulting in an increase in milk fat content and flow of trans-10 18:1 at the duodenum (Griinari et al., 1998; Piperova et al., 2002; Loor et al., 2004). Over a wide range of diets, reductions in milk fat synthesis are known to be associated with elevated milk fat trans-10 18:1 concentrations (Loor et al., 2005; Shingfield and Griinari, 2007), with the corollary that this biohydrogenation intermediate is directly or indirectly involved in the regulation of mammary lipogenesis. Postruminal infusions of a relatively pure (95\%) preparation of trans-10 18:1 provided the first direct test of the possible role of this biohydrogenation intermediate on mammary lipid metabolism (Lock et al., 2007). Administration of $42.6 \mathrm{~g}$ of trans-10 18:1/d over a 4-d period enhanced the concentrations of this isomer in milk fat from 0.47 to $1.11 \mathrm{~g} / 100 \mathrm{~g}$ of fatty acids, but had no effect on milk fat synthesis.

Under certain conditions of diet-induced MFD, ruminal outflow of trans-10 18:1 may increase to levels above $90 \mathrm{~g} / \mathrm{d}$ (Shingfield and Griinari, 2007), and milk fat trans-10 18:1 concentrations can approach or exceed $10 \mathrm{~g} / 100 \mathrm{~g}$ of fatty acids (Piperova et al., 2000; Roy et al., 2006; Shingfield et al., 2006), indicating that the supply of trans-10 18:1 at the mammary gland during diet-induced MFD is often several-fold higher than the amounts evaluated previously (Lock et al., 2007). In the current experiment, the role of trans-10 18:1 in the regulation of mammary lipogenesis was further examined based on milk fat responses to postruminal infusions of a mixture of 18:1 fatty acid methyl esters (FAME) supplying $92 \mathrm{~g} / \mathrm{d}$ of trans-10 18:1.

\section{MATERIALS AND METHODS}

\section{Animals and Experimental Design}

All procedures involving animals were approved by the Animal Experiment Committee of MTT Agrifood Research Finland in accordance with the Use of Vertebrates for Scientific Purposes Act of 1985. Three multiparous lactating Finnish Ayrshire cows (616 \pm
Table 1. Ingredient and chemical composition of the TMR

\begin{tabular}{|c|c|}
\hline Ingredient & $\%, \mathrm{DM}$ basis \\
\hline Grass silage $^{1}$ & 60.0 \\
\hline Rolled barley & 20.6 \\
\hline Molassed sugarbeet pulp & 10.1 \\
\hline Rapeseed meal $^{2}$ & 8.1 \\
\hline Minerals and vitamins ${ }^{3}$ & 1.3 \\
\hline \multicolumn{2}{|l|}{ Chemical composition } \\
\hline DM, $\%$ as fed & 49.9 \\
\hline $\mathrm{OM}$ & 92.2 \\
\hline $\mathrm{CP}$ & 15.1 \\
\hline NDF & 42.1 \\
\hline Ether extract & 3.6 \\
\hline $\mathrm{ME}, \mathrm{MJ} / \mathrm{kg}$ of $\mathrm{DM}$ & 11.32 \\
\hline
\end{tabular}

${ }^{1}$ Prepared from primary growths of mixed timothy (Phleum pratense) and meadow fescue (Festuca pratensis) swards and ensiled with a formic acid based additive declared as containing 5.5 and $76.0 \%$ of ammonium formate and formic acid, respectively (Kemira Agro Ltd., Helsinki, Finland) applied at a rate of $6.0 \mathrm{~L} / \mathrm{t}$ of grass. Mean fermentation characteristics: $\mathrm{pH} 3.96$; in DM percentage: lactic acid, 6.12; water-soluble carbohydrate, 3.45; VFA, 2.74; ethanol, 1.14; \% of total $\mathrm{N}$ : ammonium-N, 5.92; soluble $\mathrm{N}, 65.8$.

${ }^{2}$ Solvent-extracted rapeseed meal of low glucosinolate content.

${ }^{3}$ Mineral and vitamin supplement (Onni-Kivennäinen, Rehumelica, Vaasa, Finland) declared as containing (g/kg) calcium (205), magnesium (72), sodium (85), phosphorus (27), zinc (1.46), manganese (0.35), copper (0.27); $(\mathrm{mg} / \mathrm{kg})$, iodine (39), cobalt (27), selenium (20); (IU/g) retinyl acetate (120), cholecalciferol (25), and di- $\alpha$ tocopheryl acetate (0.34)

$35.9 \mathrm{~kg}$ of $\mathrm{BW}, 2.3 \pm 0.29$ parity, and $130 \pm 4.04 \mathrm{~d}$ in lactation) fitted with rumen fistula (100 mm i.d.; Bar Diamond, Parma, ID) were used. Animals were housed in individual stalls within a dedicated metabolism unit and offered a TMR (Table 1) formulated to meet or exceed nutrient requirements (MTT Agrifood Research Finland, 2006). Diets were offered ad libitum and fed as equal meals at 0800 and $1600 \mathrm{~h}$. Cows had continuous access to water and were milked at 0600 and $1700 \mathrm{~h}$.

Cows were randomly assigned treatments in a $3 \times 3$ Latin square design. Treatments comprised abomasal infusion of $60 \mathrm{~mL} / \mathrm{d}$ of $95 \%$ (vol/vol) ethanol (control), trans-10, cis-12 CLA (CLA) in FFA form, and a mixture of 18:1 FAME (T181). The CLA treatment was administered in FFA form due to availability. Previous studies have demonstrated that postruminal infusions of trans-10, cis-12 CLA as a FFA or FAME induce comparable reductions in milk fat synthesis in lactating cows (de Veth et al., 2004). Both the CLA (6.3 g/d) and T181 supplement $(247 \mathrm{~g} / \mathrm{d})$ were dissolved in $95 \%$ ( $\mathrm{vol} / \mathrm{vol}$ ) ethanol at a ratio designed to maintain the same rate of ethanol infusion $(60 \mathrm{~mL} / \mathrm{d})$ as the control. Postruminal infusion was used as a convenient means of delivering fatty acids to the small intestine, avoiding ruminal biohydrogenation and possible effects on the microbial population in the rumen and enabling the amount of fatty acids supplied by each treatment to be accurately determined. Lipid supplements were 
administered into the abomasum via Nalgene tubing that passed through the rumen fistula and reticuloomasal orifice. Lipid supplements were prepared fresh daily and treatments were infused (5 min in duration) in equal proportions at $0700,1030,1600$, and 2030 $\mathrm{h}$. On each occasion, infusion lines were manually inspected to ensure that materials were administered in the abomasum. Infusions were maintained over a 5 -d period followed by a 9-d washout interval to minimize treatment carryover effects.

\section{Lipid Supplements}

Trans-10, cis-12 CLA was synthesized from refined safflower oil (Sæbø et al., 2005). The 18:1 FAME supplement was prepared by Natural ASA (Hovdebygda, Norway) using a mixture of CLA methyl esters predominating in cis-9, trans-11 and trans-10, cis-12 as the starting material. The CLA isomer mixture was dissolved in dimethylacetamide and partially hydrogenated to 18:1 FAME in a continuous flow cell hydrogenation apparatus, using palladium as a catalyst.

Lipid supplements were stored at $4^{\circ} \mathrm{C}$ under oxygenfree nitrogen before infusion. The fatty acid composition of CLA and T181 supplements was determined based on complementary GC-flame-ionization detection, GC-MS, and Ag+ HPLC analysis. Nonesterified fatty acids in the CLA supplement were converted to FAME using $1 \%$ (vol/vol) sulfuric acid in methanol at $50^{\circ} \mathrm{C}$ for $30 \mathrm{~min}$ (Shingfield et al., 2003). Methyl esters were quantified using a gas chromatograph (model 6890, Hewlett-Packard, Wilmington, DE) equipped with a flame-ionization detector and a 100-m fused silica capillary column (i.d. $0.25 \mathrm{~mm}$ ) coated with a $0.2-\mu \mathrm{m}$ film of cyanopropyl polysiloxane (CP-SIL 88, Chrompack 7489, Middelburg, the Netherlands). Injector and detector temperatures were maintained at $255^{\circ} \mathrm{C}$. Total FAME profile in a $2-\mu \mathrm{L}$ sample volume at a split ratio of 1:50 was determined using a temperature gradient program with hydrogen as the carrier gas operated at constant pressure $(137.9 \mathrm{kPa})$ at a flow rate of $0.5 \mathrm{~mL} /$ min (Shingfield et al., 2003). Isomers of 18:1 and 18:2 were further resolved in a separate analysis under isothermal conditions at $170^{\circ} \mathrm{C}$ (Shingfield et al., 2003). Peaks were identified based on retention time comparisons with authentic standards (GLC \#463 and GLC \#606, Nu-Chek Prep, Elysian, MN). Methyl esters not contained in commercially available standards were formally identified by GC-MS analysis of 4,4-dimethyloxazoline fatty acid (DMOX) derivatives prepared from FAME by incubation overnight with 2-amino, 2-methyl-1-propanol under a nitrogen atmosphere at $150^{\circ} \mathrm{C}$ (Shingfield et al., 2006). Impact ionization spectra of DMOX derivatives were obtained using an identical gas chromatograph equipped with a selective quadrupole mass detector (model 5973N, Agilent Technologies Inc., Wilmington, DE), under an ionization energy of $70 \mathrm{eV}$. Chromatography was achieved using the same temperature gradient applied for the analysis of FAME and helium as the carrier gas (Shingfield et al., 2006). Double bond geometry was determined based on atomic mass unit distances, with an interval of 12 atomic mass units between the most intense peaks of clusters of ions containing $\mathrm{n}$ and $\mathrm{n}-1$ carbon atoms being interpreted as cleavage of the double bond between carbon $n$ and $n+1$ in the fatty acid moiety.

The distribution of CLA isomers in lipid supplements was determined using a HPLC system (model 1090, Hewlett-Packard) equipped with 4 silver impregnated silica columns (ChromSpher 5 Lipids, $250 \times 4.6 \mathrm{~mm} ; 5$ $\mu \mathrm{m}$ particle size, Varian Ltd., Walton-on-Thames, UK) coupled in series. Methyl esters of CLA were separated under isocratic conditions at $22^{\circ} \mathrm{C}$ using $0.1 \%$ (vol/ vol) acetonitrile in heptane at a flow rate of $1 \mathrm{~mL} /$ min and monitoring column effluent at 233 and $210 \mathrm{~nm}$ (Shingfield et al., 2003). Under these conditions, cis-10, trans-12 and trans-10, cis-12 CLA co-elute (Sæbø et al., 2005), and therefore, the analysis of lipid supplements was repeated using $2.0 \%$ ( $\mathrm{vol} / \mathrm{vol}$ ) acetic acid in heptane as the mobile phase (Shingfield et al., 2005). Typical injection volumes were 10 to $20 \mu \mathrm{L}$, representing $<250 \mu \mathrm{g}$ of lipid. Identification of CLA isomers was performed using commercially available CLA methyl ester standards (Matreya Inc., Pleasant Gap, PA; Sigma, St. Louis, MO) and comparison with the elution order reported in the literature (Delmonte et al., 2005).

\section{Measurements, Sample Collection, and Chemical Analysis}

Individual cow intakes were measured daily during each infusion period. Representative samples of TMR and refused feed were composited daily and stored at $-20^{\circ} \mathrm{C}$. Chemical composition and nutritive value of experimental feeds was determined using reference methods (Shingfield et al., 2001). Milk yield and DM intake were recorded daily throughout the 42-d experiment. Samples of milk for the determination of fat, $\mathrm{CP}$, and lactose were collected from each cow at each milking for the entire experiment. Milk samples treated with preservative (Bronopol, Valio Ltd., Helsinki, Finland) were stored at $4^{\circ} \mathrm{C}$ until analyzed for milk fat, $\mathrm{CP}$, and lactose by near infrared analysis (Shingfield et al., 2001). Fatty acid composition was determined in untreated samples of milk collected during the last 24 $\mathrm{h}$ of each infusion period and composited according to yield. Milk samples for fatty acid determinations were stored at $-20^{\circ} \mathrm{C}$ until submitted for analysis. 
Lipid in $1 \mathrm{~mL}$ of milk was extracted in duplicate using diethylether and hexane (5:4, by vol) according to reference procedures (IDF 1C:1987; IDF 16C:1987; IDF, 1987). Extracts were combined and evaporated to dryness at $60^{\circ} \mathrm{C}$ under oxygen-free nitrogen for $1 \mathrm{~h}$. Samples were dissolved in hexane and methyl acetate and transesterified to FAME using freshly prepared methanolic sodium methoxide (Christie, 1982) with modifications (Shingfield et al., 2003). The FAME prepared from samples of milk fat was quantified by GC using the same temperature gradient and isothermal analysis applied to lipid supplements. Methyl esters not contained in commercially available standards were formally identified by GC-MS analysis of DMOX derivatives prepared from milk fat FAME (Shingfield et al., 2006). Analysis of milk fat CLA isomer profile was determined by HPLC using $0.1 \%$ (vol/vol) acetonitrile in heptane as the mobile phase. Milk fatty acid composition was expressed as a weight percentage of total fatty acids using theoretical relative response factors (Craske and Bannon, 1988; Ulberth et al., 1999), and milk fat fatty acid content was determined using tritridecanoin (Nu-Chek Prep) as an internal standard (Shingfield et al., 2003). Concentrations of specific conjugated isomers in CLA supplements were calculated based on proportionate peak area responses determined by HPLC and the sum of trans-7, cis-9 CLA, trans-8, cis-10 CLA and cis-9, trans-11 CLA weight percentage determined by GC.

\section{Statistical Analysis}

Mean nutrient intake and milk production data measured over the last $48 \mathrm{~h}$ of abomasal infusion were evaluated by ANOVA for a $3 \times 3$ Latin square design using the mixed procedure of SAS (Version 9.1, SAS Institute Inc., Cary, NC) with a model that included the random effects of cow and fixed effects of period and experimental treatment. Milk fatty acid composition data determined in samples collected over the last $24 \mathrm{~h}$ of each treatment period were analyzed using the same statistical model. Milk production data collected over the course of the experiment were also subjected to ANOVA for repeated measures using the mixed linear model procedure of SAS with a statistical model that included the fixed effects of diet, time, and their interaction, and the random effects of cow assuming an autoregressive order one covariance structure fitted on the basis of Akaike information and Schwarz Bayesian model-fit criteria. Least squares means are reported and treatment effects declared significant at $P<0.05$. Differences between treatments at $P<0.10$ were considered as a trend toward significance.
Table 2. Fatty acid composition of lipid supplements

\begin{tabular}{lrr}
\hline & \multicolumn{2}{c}{ Supplement $^{1}$} \\
\cline { 2 - 3 } Fatty acid, g/100 g & CLA & T181 \\
\hline $16: 0$ & 0.00 & 0.34 \\
$18: 0$ & 0.04 & 3.78 \\
cis-9 $18: 1$ & 0.31 & 9.45 \\
cis-10 18:1 & 0.00 & 1.31 \\
cis-11 18:1 & 0.00 & 1.30 \\
cis-12 18:1 & 0.00 & 3.35 \\
trans-8 18:1 & 0.00 & 0.35 \\
trans-9 18:1 & 0.00 & 1.65 \\
trans-10 18:1 & 0.00 & 37.32 \\
trans-11 18:1 & 0.00 & 37.35 \\
trans-12 18:1 $18: 1$ & 0.00 & 2.66 \\
18: 1 total & 0.00 & 0.59 \\
cis-9, cis-12 18:2 & 0.31 & 95.33 \\
cis-9, trans-12 18:2 & 0.03 & 0.20 \\
trans-9, cis-12 18:2 & 0.00 & 0.10 \\
trans- 9, trans-12 18:2 & 0.00 & 0.09 \\
cis-9, cis-11 CLA & 0.00 & 0.04 \\
cis-10, cis-12 CLA & 0.02 & 0.00 \\
cis-9, trans-11 CLA & 0.03 & 0.00 \\
cis-11, trans-13 CLA & 3.54 & 0.00 \\
trans-10, cis-12 CLA & 0.02 & 0.00 \\
trans-9, trans-11 CLA & 95.71 & 0.00 \\
trans-10, trans-12 CLA & 0.04 & 0.00 \\
CLA total & 0.09 & 0.00 \\
\hline
\end{tabular}

${ }^{1}$ CLA $=$ conjugated linoleic acid; T181 $=$ a mixture of 18:1 fatty acid methyl esters.

\section{RESULTS}

The CLA supplement was relatively pure and contained $96 \%$ trans-10, cis-12 CLA (Table 2). Detailed structural analysis established that the T181 supplement contained a high proportion of 18:1 isomers (95.3\%) with trans-10 18:1 and trans-11 18:1 as the major components (Figure 1 and Table 2). Complementary GC-MS analysis of DMOX derivatives and $\mathrm{Ag}+\mathrm{HPLC}$ confirmed that the T181 supplement was devoid of CLA isomers. Abomasal infusion of the CLA supplement supplied the targeted amount of trans-10, cis-12 CLA (6.03 g/d). Administration of the T181 lipid supplements delivered (g/d) 16:0 (0.83), 18:0 (9.32), cis-9 18:1 (23.3), cis-10 18:1 (3.24), cis-11 18:1 (3.20), cis-12 18:1 (8.26), trans-8 18:1 (0.86), trans-9 18:1 (4.08), trans-10 18:1 (92.1), trans-11 18:1 (92.1), trans-12 18:1 (6.55), and trans-13 18:1 (1.46) at the abomasum.

Postruminal infusions of lipid supplements had no effect on DM intake or milk yield (Table 3). Compared with the control, the T181 and CLA treatments resulted in 21.3 and $41.4 \%$ reductions in milk fat content, and 19.5 and $41.5 \%$ decreases in milk fat output, respectively (Table 3). Administration of both lipid supplements resulted in progressive reductions in milk fat concentration and secretion over the 5 -d treatment 
period (Figure 2). With the exception of an increase $(P$ $<0.05)$ in lactose concentration and higher $(P<0.05)$ SCC in milk of cows infused with CLA, postruminal infusion of experimental treatments had no effect on the concentration or output of other milk constituents (Table 3).

Relative to the control, administration of CLA at the abomasum decreased $(P<0.05)$ milk fat 12:0, cis-9 12:1, trans-9 12:1, 14:0, and 16:0 concentrations, reduced $(P<0.05)$ cis-9 10:1/10:0, cis-9 12:1/12:0 and cis-9, trans-11 CLA/trans-11 18:1 concentration ratios, and enhanced $(P<0.05)$ 13:0 anteiso, 18:0, 18:2, 18:3n-3, 20:0, cis 20:1, and 21:0 content (Table 4). Postruminal infusions of CLA also tended $(P=0.07)$ to decrease 10:0 concentrations and increase $(P=0.06)$ milk total CLA content compared with the control (Table 4). Administration of CLA at the abomasum enhanced $(P<0.05)$ milk fat trans-10, cis-12 CLA con-
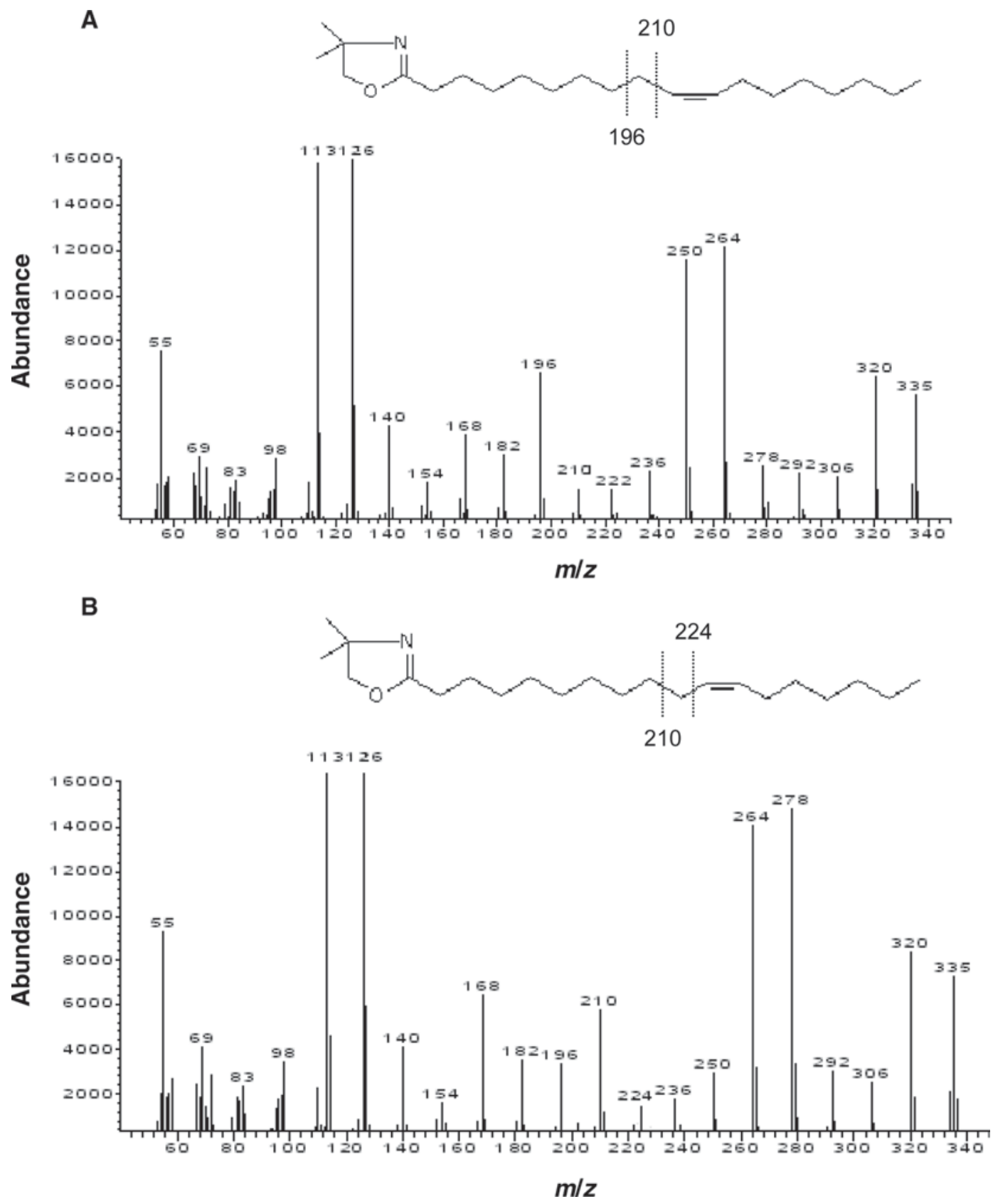

Figure 1. Mass spectrum of the 4,4-dimethyloxaline (DMOX) derivative of trans-10 18:1 (A) and trans-11 18:1 (B) that represented major components in a mixture of methyl esters (T181) infused at the abomasum in lactating cows. 

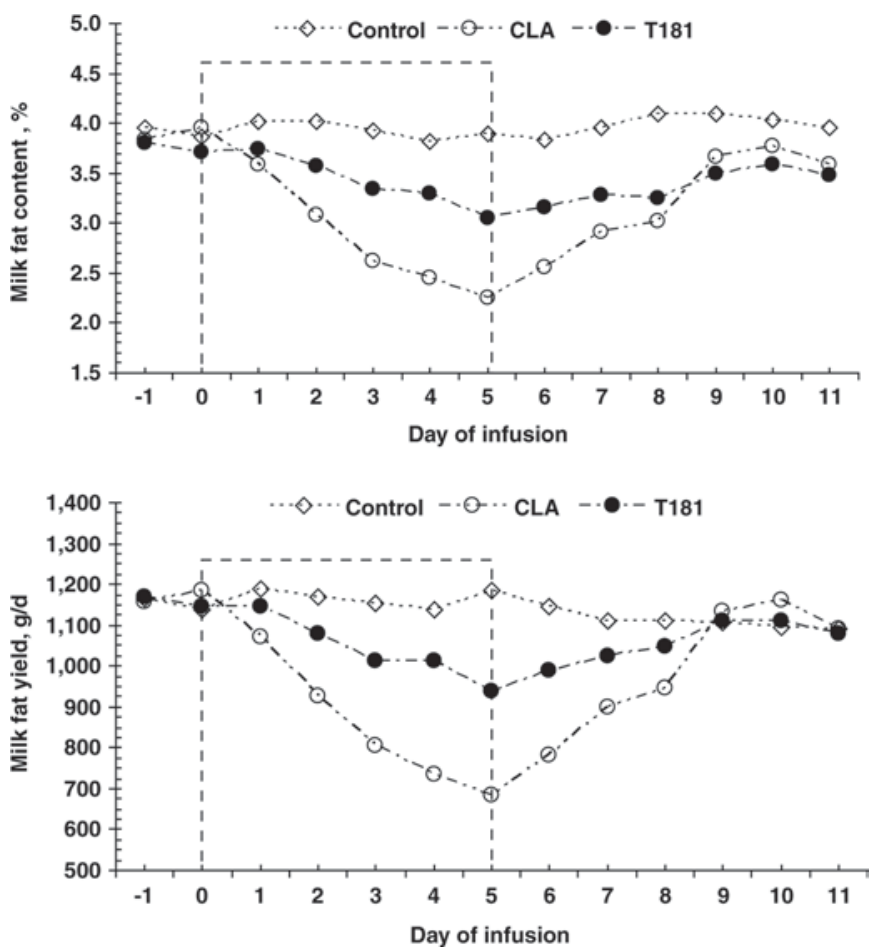

Figure 2. Temporal changes in milk fat content and milk fat yield during abomasal infusion of ethanol (control) or the same amount of ethanol and lipid supplements containing trans-10, cis-12 conjugated linoleic acid (CLA) or a mixture of 18:1 methyl esters containing trans-10 18:1 and trans-11 18:1 as major isomers (T181). Infusion period of $5 \mathrm{~d}$ is indicated by the dotted line. Values represent least squares means $(\mathrm{n}=3)$. Standard error of the means for milk fat content and milk fat yield was $0.146 \%$ and $88.2 \mathrm{~g} / \mathrm{d}$, respectively.

tent, an enrichment that was accompanied by relatively minor but often significant effects on the concentration of other 18:2 isomers (Table 5). Decreases in milk fat to postruminal infusions of the CLA treatment were attributable to both a reduction in the secretion of fatty acids synthesized de novo and preformed fatty acids extracted from the peripheral circulation (Figure 3). However, the larger reduction in the secretion of short and medium chain fatty acids (4:0 to 14:0) resulted in an overall increase in the proportion of milk fat longchain fatty acids. Administration of CLA enhanced ( $P$ $<0.01)$ trans-10, cis-12 CLA secretion in milk fat from 0.049 to $1.53 \mathrm{~g} / \mathrm{d}$ associated with a mean efficiency of transfer from the abomasum into milk of $24.6 \pm$ $2.41 \%$.

Reductions in milk fat secretion to the T181 supplement were associated with decreases $(P<0.05)$ in the concentration of fatty acids synthesized de novo (12:0, 14:0, and 16:0), an increase in trans 18:1 content, and a trend $(P=0.06)$ toward elevated CLA concentrations (Table 4). Enrichment of milk trans 18:1 concentrations were related to the relative abundance of specific isomers contained in the infused T181 supplement (Table 5). Other than a decrease $(P<0.01)$ in the cis-9 10:1/10:0 and cis-9, trans-11 CLA/trans-11 18:1 concentration ratios, milk fatty acid composition responses to the T181 supplement were not associated $(P$ $>0.10)$ with alterations in product-to-substrate ratios for $\Delta^{9}$-desaturase (Table 4). Postruminal infusion of the T181 treatment at the abomasum enhanced $(P<0.05)$ milk fat trans- 8 , cis-10 CLA and trans-10, trans -12 CLA content and tended $(P=0.06)$ to increase trans-8, trans-10 CLA and cis-9, trans-11 CLA concentrations (Table 5). Reductions in milk fat synthesis to the T181 supplement were explained by a decrease in the secretion of fatty acids synthesized de novo, whereas the output of long-chain fatty acids was unaffected (Figure 3 ). Correcting for endogenous concentrations indicated that $40.7 \pm 1.41 \%$ of trans-10 18:1 administered at the abomasum was apparently transferred to the mammary gland and incorporated into milk fat triacylglycerols

Table 3. Effect of abomasal infusion of lipid supplements on intake, milk yield, and milk composition in lactating cows ${ }^{1}$

\begin{tabular}{lccccc}
\hline & \multicolumn{3}{c}{ Treatment $^{2}$} \\
\cline { 2 - 3 } Variable & Control & CLA & T181 & SEM & P-value \\
\cline { 2 - 4 } DMI, kg/d & 22.0 & 20.9 & 20.6 & 0.63 & 0.431 \\
Milk, kg/d & 30.1 & 30.0 & 30.7 & 0.34 & 0.464 \\
Milk fat, \% & $4.03^{\mathrm{a}}$ & $2.36^{\mathrm{c}}$ & $3.17^{\mathrm{b}}$ & 0.146 & 0.034 \\
Milk fat, g/d & $1,211^{\mathrm{a}}$ & $708^{\mathrm{c}}$ & $975^{\mathrm{b}}$ & 36.3 & 0.020 \\
Milk protein, \% & 3.35 & 3.36 & 3.37 & 0.027 & 0.869 \\
Milk protein, g/d & 1,005 & 1,002 & 1,028 & 8.45 & 0.268 \\
Milk lactose, \% & $4.86^{\mathrm{b}}$ & $4.93^{\mathrm{a}}$ & $4.93^{\mathrm{a}}$ & 0.009 & 0.047 \\
Milk lactose, g/d & 1,465 & 1,478 & 1,512 & 17.7 & 0.347 \\
SCC, $10^{3}$ cells/mL & $28.5^{\mathrm{b}}$ & $60.8^{\mathrm{a}}$ & $32.7^{\mathrm{b}}$ & 3.50 & 0.038 \\
\hline
\end{tabular}

${ }^{\mathrm{a}-\mathrm{c}}$ Means within a row not sharing common superscripts differ $(P<0.05)$.

${ }^{1}$ Values represent means of d 4 and 5 of infusion for 3 cows.

${ }^{2}$ Treatments consisted of abomasal infusions of $60 \mathrm{~g}$ of ethanol/d (control); $60 \mathrm{~g}$ of ethanol/d and $6.0 \mathrm{~g} / \mathrm{d}$ of trans-10, cis-12 conjugated linoleic acid (CLA); or $60 \mathrm{~g}$ of ethanol/d and $247 \mathrm{~g} / \mathrm{d}$ of a mixture of 18:1 fatty acid methyl esters (T181) administered at 6-h intervals over a 5-d treatment period. 
Table 4 . Effect of abomasal infusion of lipid supplements on milk fatty acid composition ${ }^{1}$

\begin{tabular}{|c|c|c|c|c|c|}
\hline \multirow[b]{2}{*}{ Fatty acid, g/100 g } & \multicolumn{3}{|c|}{ Treatment $^{2}$} & \multirow[b]{2}{*}{ SEM } & \multirow[b]{2}{*}{$P$-value } \\
\hline & Control & CLA & $\mathrm{T} 181$ & & \\
\hline 4:0 & 4.22 & 4.14 & 3.84 & 0.203 & 0.504 \\
\hline $6: 0$ & 2.43 & 1.85 & 1.98 & 0.110 & 0.116 \\
\hline $8: 0$ & 1.37 & 1.00 & 1.08 & 0.065 & 0.105 \\
\hline 10:0 & 2.88 & 2.15 & 2.21 & 0.108 & 0.065 \\
\hline cis-9 10:1 & $0.38^{\mathrm{a}}$ & $0.18^{\mathrm{b}}$ & $0.25^{\mathrm{b}}$ & 0.013 & 0.015 \\
\hline $12: 0$ & $3.39^{\mathrm{a}}$ & $2.81^{\mathrm{b}}$ & $2.66^{\mathrm{b}}$ & 0.084 & 0.046 \\
\hline cis-9 12:1 & $0.10^{\mathrm{a}}$ & $0.05^{\mathrm{b}}$ & $0.07^{\mathrm{c}}$ & 0.001 & 0.003 \\
\hline trans-9 12:1 & $0.10^{\mathrm{a}}$ & $0.05^{\mathrm{c}}$ & $0.07^{\mathrm{b}}$ & $<0.001$ & $<0.001$ \\
\hline 13:0 iso & 0.03 & 0.03 & 0.03 & 0.001 & 0.171 \\
\hline 13:0 anteiso & $0.011^{\mathrm{b}}$ & $0.014^{\mathrm{a}}$ & $0.012^{\mathrm{b}}$ & 0.0003 & 0.024 \\
\hline $14: 0$ & $12.13^{\mathrm{a}}$ & $11.52^{\mathrm{b}}$ & $10.47^{\mathrm{c}}$ & 0.083 & 0.010 \\
\hline 14:0 iso & 0.08 & 0.10 & 0.09 & 0.004 & 0.097 \\
\hline cis-9 14:1 & 1.18 & 0.92 & 1.26 & 0.058 & 0.096 \\
\hline trans-9 14:1 & 0.015 & 0.016 & 0.015 & 0.0009 & 0.513 \\
\hline $15: 0$ & 0.98 & 1.04 & 0.90 & 0.048 & 0.311 \\
\hline 15:0 iso & 0.23 & 0.24 & 0.21 & 0.009 & 0.187 \\
\hline 15:0 anteiso & $0.45^{\mathrm{b}}$ & $0.55^{\mathrm{a}}$ & $0.44^{\mathrm{b}}$ & 0.013 & 0.044 \\
\hline cis-9 15:1 & 0.04 & 0.04 & 0.04 & 0.001 & 0.067 \\
\hline trans-5 15:1 & $0.05^{\mathrm{b}}$ & $0.06^{\mathrm{a}}$ & $0.05^{\mathrm{b}}$ & 0.001 & 0.040 \\
\hline trans-9 15:1 & 0.01 & 0.01 & 0.01 & 0.002 & 0.768 \\
\hline $16: 0$ & $34.83^{\mathrm{a}}$ & $27.64^{\mathrm{b}}$ & $25.81^{\mathrm{b}}$ & 0.670 & 0.019 \\
\hline 16:0 iso & 0.20 & 0.27 & 0.22 & 0.009 & 0.077 \\
\hline cis-9 16:1 & 1.36 & 1.13 & 1.39 & 0.037 & 0.061 \\
\hline cis-11 16:1 & 0.04 & 0.06 & 0.04 & 0.004 & 0.089 \\
\hline cis-13 16:1 & 0.02 & 0.03 & 0.02 & 0.002 & 0.117 \\
\hline trans $16: 1^{3}$ & 0.50 & 0.65 & 0.83 & 0.055 & 0.103 \\
\hline 16:1 total & 1.92 & 1.88 & 2.28 & 0.084 & 0.124 \\
\hline $17: 0$ & 0.48 & 0.62 & 0.46 & 0.024 & 0.071 \\
\hline $17: 0$ iso & 0.12 & 0.15 & 0.11 & 0.007 & 0.521 \\
\hline 17:0 anteiso & $0.22^{\mathrm{b}}$ & $0.33^{\mathrm{a}}$ & $0.22^{\mathrm{b}}$ & 0.012 & 0.035 \\
\hline cis-7 17:1 & 0.03 & 0.04 & 0.02 & 0.003 & 0.121 \\
\hline cis-8 $17: 1$ & $0.09^{\mathrm{b}}$ & $0.13^{\mathrm{a}}$ & $0.10^{\mathrm{b}}$ & 0.004 & 0.027 \\
\hline cis-9 17:1 & 0.14 & 0.15 & 0.14 & 0.005 & 0.589 \\
\hline $18: 0$ & $9.52^{\mathrm{b}}$ & $13.50^{\mathrm{a}}$ & $9.67^{\mathrm{b}}$ & 0.385 & 0.028 \\
\hline 18:0 iso & $0.04^{\mathrm{b}}$ & $0.06^{\mathrm{a}}$ & $0.05^{\mathrm{b}}$ & 0.001 & 0.010 \\
\hline cis-9 $18: 1^{4}$ & 14.16 & 18.06 & 17.22 & 0.622 & 0.084 \\
\hline cis-11 18:1 & 0.41 & 0.54 & 0.60 & 0.058 & 0.255 \\
\hline cis-12 18:1 & 0.15 & 0.18 & 0.56 & 0.107 & 0.181 \\
\hline cis-13 18:1 & 0.06 & 0.07 & 0.06 & 0.010 & 0.896 \\
\hline cis-15 18:1 & 0.16 & 0.21 & 0.18 & 0.006 & 0.068 \\
\hline cis-16 18:1 & 0.06 & 0.08 & 0.09 & 0.018 & 0.641 \\
\hline trans-4 18:1 & 0.03 & 0.05 & 0.04 & 0.010 & 0.606 \\
\hline trans-5 18:1 & 0.03 & 0.04 & 0.03 & 0.011 & 0.760 \\
\hline trans $-6+7+818: 1$ & $0.17^{\mathrm{b}}$ & $0.26^{\mathrm{a}}$ & $0.21^{\mathrm{a}}$ & 0.008 & 0.024 \\
\hline trans-9 $18: 1$ & 0.17 & 0.21 & 0.40 & 0.062 & 0.208 \\
\hline trans-10 18:1 & $0.17^{\mathrm{b}}$ & $0.32^{\mathrm{b}}$ & $4.37^{\mathrm{a}}$ & 0.291 & 0.015 \\
\hline trans-11 18:1 & $0.85^{\mathrm{b}}$ & $1.23^{\mathrm{b}}$ & $3.96^{\mathrm{a}}$ & 0.216 & 0.016 \\
\hline trans-12 18:1 & 0.22 & 0.28 & 0.49 & 0.051 & 0.112 \\
\hline trans- $13+14$ 18:1 & $0.59^{\mathrm{b}}$ & $0.72^{\mathrm{a}}$ & $0.58^{\mathrm{b}}$ & 0.013 & 0.026 \\
\hline trans-15 18:1 & 0.40 & 0.50 & 0.50 & 0.036 & 0.295 \\
\hline trans-16 $18: 1^{5}$ & $0.32^{\mathrm{b}}$ & $0.41^{\mathrm{a}}$ & $0.33^{\mathrm{b}}$ & 0.009 & 0.032 \\
\hline $18: 1$ cis & 15.00 & 19.13 & 18.71 & 0.792 & 0.108 \\
\hline $18: 1$ trans & $2.94^{\mathrm{b}}$ & $4.02^{\mathrm{b}}$ & $10.91^{\mathrm{a}}$ & 0.687 & 0.025 \\
\hline $18: 1$ total & 17.94 & 23.15 & 29.62 & 1.469 & 0.059 \\
\hline $18: 2$ total $^{6}$ & $1.77^{\mathrm{b}}$ & $2.20^{\mathrm{a}}$ & $1.88^{\mathrm{a}}$ & 0.036 & 0.027 \\
\hline CLA total & 0.46 & 0.79 & 1.72 & 0.167 & 0.061 \\
\hline $18: 3 n-3$ & $0.47^{\mathrm{b}}$ & $0.61^{\mathrm{a}}$ & $0.48^{\mathrm{b}}$ & 0.005 & 0.004 \\
\hline cis-9, trans- 11, cis-15 18:3 & $0.043^{\mathrm{ab}}$ & $0.047^{\mathrm{a}}$ & $0.039^{\mathrm{b}}$ & 0.0009 & 0.046 \\
\hline $20: 0$ & $0.14^{\mathrm{b}}$ & $0.18^{\mathrm{a}}$ & $0.13^{\mathrm{b}}$ & 0.004 & 0.018 \\
\hline cis $-6+7+8 \quad 20: 1$ & $0.01^{\mathrm{b}}$ & $0.01^{\mathrm{b}}$ & $0.16^{\mathrm{a}}$ & 0.0009 & 0.029 \\
\hline cis-9 20:1 & $0.12^{\mathrm{b}}$ & $0.14^{\mathrm{a}}$ & $0.12^{\mathrm{b}}$ & 0.001 & 0.006 \\
\hline cis-11 20:1 & $0.04^{\mathrm{b}}$ & $0.06^{\mathrm{a}}$ & $0.05^{\mathrm{b}}$ & 0.001 & 0.010 \\
\hline $21: 0$ & 0.03 & 0.06 & 0.03 & 0.004 & 0.072 \\
\hline $22: 0$ & 0.05 & 0.06 & 0.05 & 0.002 & 0.102 \\
\hline
\end{tabular}


Table 4 (Continued). Effect of abomasal infusion of lipid supplements on milk fatty acid composition ${ }^{1}$

\begin{tabular}{lccccc}
\hline & \multicolumn{3}{c}{ Treatment $^{2}$} & & \\
\cline { 2 - 4 } Fatty acid, g/100 g & Control & CLA & T181 & SEM & P-value \\
\hline Other & 0.26 & 0.30 & 0.24 & 0.014 & 0.185 \\
Unidentified & 0.53 & 0.43 & 0.48 & 0.029 & 0.215 \\
Fatty acids, g/100 g of fat & 95.0 & 95.0 & 95.3 & 0.143 & 0.407 \\
Ratio & & & & & \\
cis-9 10:1/10:0 & $0.133^{\mathrm{a}}$ & $0.082^{\mathrm{c}}$ & $0.114^{\mathrm{b}}$ & 0.0020 & 0.006 \\
cis-9 12:1/12:0 & $0.028^{\mathrm{a}}$ & $0.017^{\mathrm{b}}$ & $0.026^{\mathrm{a}}$ & 0.0008 & 0.017 \\
cis-9 14:1/14:0 & 0.098 & 0.080 & 0.123 & 0.0077 & 0.113 \\
cis-9 16:1/16:0 & 0.039 & 0.041 & 0.055 & 0.0035 & 0.130 \\
cis-9 17:1/17:0 & 0.298 & 0.245 & 0.320 & 0.0209 & 0.228 \\
cis-9 18:1/18:0 & 1.507 & 1.346 & 1.790 & 0.1105 & 0.195 \\
cis-9, trans-11 CLA/trans-11 18:1 & $0.423^{\mathrm{a}}$ & $0.347^{\mathrm{c}}$ & $0.392^{\mathrm{b}}$ & 0.0037 & 0.009 \\
\hline
\end{tabular}

${ }^{a-c}$ Means within a row not sharing common superscripts differ $(P<0.05)$.

${ }^{1}$ Values represent means for d 5 of infusion for 3 cows.

${ }^{2}$ Treatments consisted of abomasal infusions of $60 \mathrm{~g}$ of ethanol/d (control); $60 \mathrm{~g}$ of ethanol/d and $6.0 \mathrm{~g} / \mathrm{d}$ of trans-10, cis-12 conjugated linoleic acid (CLA); or $60 \mathrm{~g}$ of ethanol/d and $247 \mathrm{~g} / \mathrm{d}$ of a mixture of 18:1 fatty acid methyl esters (T181) administered at 6-h intervals over a 5-d treatment period.

${ }^{3}$ Sum of trans-5 16:1, trans-6-8 16:1, trans-9 to trans-13 16:1, and trans-15 16:1.

${ }^{4}$ Contains cis-10 18:1 as a minor component.

${ }^{5}$ Coelutes with cis-14 18:1.

${ }^{6}$ Total 18:2 excluding isomers of CLA

(TAG). Relative to the control, infusion of treatment T181 also increased $(P<0.01)$ trans-11 $18: 1$ and cis9, trans-11 CLA output in milk. Apparent recovery of infused trans-11 18:1 as the sum of trans-11 18:1 and cis-9, trans-11 CLA in milk averaged $39.4 \pm 2.27 \%$. Changes in milk fatty acid secretion indicated that 27.5 $\pm 2.65 \%$ of infused trans-11 18:1 was desaturated and secreted as cis-9, trans-11 CLA in milk fat.

\section{DISCUSSION}

Diets causing MFD are known to alter ruminal lipid metabolism leading to the formation and increased ruminal outflow of specific biohydrogenation intermediates that directly inhibit milk fat synthesis (Bauman and Griinari, 2003; Shingfield and Griinari, 2007). Postruminal infusion studies have established unequivocally that trans-10, cis-12 CLA reduces milk fat secretion in the lactating cow (Baumgard et al., 2001; Peterson et al., 2002; de Veth et al., 2004), and also have provided evidence that trans-9, cis-11 CLA (Perfield et al., 2007) and cis-10, trans-12 CLA (Sæbø et al., 2005) may exert antilipogenic effects. However, the increase in rumen outflow of biohydrogenation intermediates known to inhibit milk fat synthesis is unable to account entirely for the observed reductions in milk fat secretion during diet-induced MFD, suggesting that other fatty acid metabolites or mechanisms, or both, are involved (Shingfield and Griinari, 2007). Over a range of diets, reductions in milk fat synthesis in the lactating cow are associated with increases in ruminal trans-10 18:1 outflow (Loor et al., 2004; Shingfield and Griinari, 2007) and milk fat trans-10 18:1 content (Loor et al., 2005; Shingfield and Griinari, 2007). Because of the close inverse relationship with milk fat secretion, trans-10 18:1 has often been implicated as a putative milk fat inhibitor (Piperova et al., 2004; Loor et al., 2005; Roy et al., 2006).

A recent study reported the first direct test of the effect of postruminal infusions of trans-10 18:1 on milk fat synthesis in lactating cows. Even though appreciable

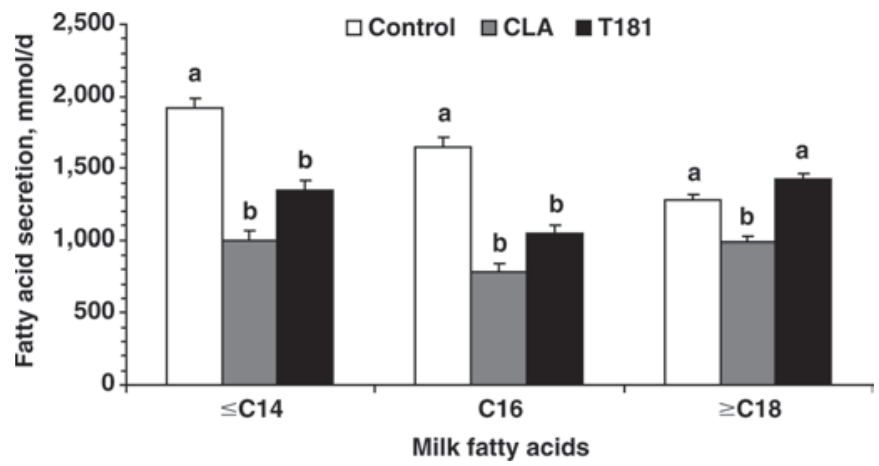

Figure 3. Milk fatty acid secretion $(\mathrm{mmol} / \mathrm{d})$ in cows receiving abomasal infusion of ethanol (control) or the same amount of ethanol and lipid supplements containing trans-10, cis-12 conjugated linoleic acid (CLA) or a mixture of 18:1 methyl esters with trans-10 18:1 and trans-11 18:1 as major isomers (T181). Values represent least squares means $(\mathrm{n}=3)$ on $\mathrm{d} 5$ of treatment. Fatty acids are categorized according to metabolic origin: $\leq$ C14 synthesized de novo, $\geq$ C18 extracted and incorporated into milk fat from circulating plasma lipids, and C16 derived from both sources. Error bars indicate SEM for $\mathrm{n}=9$ measurements. ${ }^{\mathrm{a}, \mathrm{b}}$ Columns not sharing a common letter differ at $P<0.05$. 
Table 5. Effect of abomasal infusion of lipid supplements on milk 18:2 composition ${ }^{1}$

\begin{tabular}{|c|c|c|c|c|c|}
\hline \multirow[b]{2}{*}{ Fatty acid, mg/100 g } & \multicolumn{3}{|c|}{ Treatment $^{2}$} & \multirow[b]{2}{*}{ SEM } & \multirow[b]{2}{*}{$P$-value } \\
\hline & Control & CLA & $\mathrm{T} 181$ & & \\
\hline cis-9, cis-12 18:2 & $1,261^{\mathrm{b}}$ & $1,586^{\mathrm{a}}$ & $1,317^{\mathrm{b}}$ & 36.0 & 0.041 \\
\hline cis-9, trans-12 18:2 & 90.5 & 101 & 107 & 9.04 & 0.549 \\
\hline cis-9, trans-13 18:2 & 158 & 169 & 188 & 13.7 & 0.455 \\
\hline trans -9, cis-12 18:2 & 21.2 & 29.7 & 35.2 & 5.34 & 0.366 \\
\hline trans-11, cis-15 18:2 & 164 & 215 & 157 & 8.7 & 0.068 \\
\hline trans -12, cis-15 $18: 2$ & 40.5 & 39.5 & 30.9 & 3.02 & 0.247 \\
\hline trans -9, trans $-12 \quad 18: 2$ & 7.0 & 8.1 & 10.8 & 2.62 & 0.647 \\
\hline trans-11, trans-15 18:2 & $32.4^{\mathrm{b}}$ & $46.9^{\mathrm{a}}$ & $34.6^{\mathrm{b}}$ & 1.39 & 0.031 \\
\hline cis-8, cis-10 CLA & 0.8 & 0.4 & 0.2 & 0.11 & 0.119 \\
\hline cis-9, cis-11 CLA & 2.1 & 1.6 & 1.0 & 0.30 & 0.076 \\
\hline cis-10, cis-12 CLA & $<0.1$ & 1.3 & 0.6 & 0.41 & 0.272 \\
\hline cis-11, trans-13 CLA & 1.8 & 1.4 & 1.6 & 0.13 & 0.361 \\
\hline cis-9, trans-11 CLA & 350 & 424 & 1,586 & 177.5 & 0.062 \\
\hline trans-7, cis-9 CLA & 23.3 & 24.1 & 29.7 & 1.31 & 0.127 \\
\hline trans-8, cis-10 CLA & 8.1 & 16.3 & 17.6 & 1.28 & 0.059 \\
\hline trans-10, cis-12 CLA & $4.1^{\mathrm{b}}$ & $230^{\mathrm{a}}$ & $4.0^{\mathrm{b}}$ & 14.81 & 0.013 \\
\hline trans-11, cis-13 CLA & $17.0^{\mathrm{b}}$ & $23.6^{\mathrm{a}}$ & $17.4^{\mathrm{b}}$ & 0.51 & 0.018 \\
\hline trans- 12 , cis-14 CLA & $0.7^{\mathrm{b}}$ & $1.7^{\mathrm{a}}$ & $0.9^{\mathrm{b}}$ & 0.11 & 0.045 \\
\hline trans-13, cis-15 CLA & 4.4 & 5.3 & 4.0 & 0.25 & 0.130 \\
\hline trans-7, trans-9 CLA & 1.3 & 2.1 & 1.7 & 0.13 & 0.095 \\
\hline trans-8, trans-10 CLA & $1.1^{\mathrm{b}}$ & $2.8^{\mathrm{a}}$ & $3.0^{\mathrm{a}}$ & 0.13 & 0.017 \\
\hline trans-9, trans-11 CLA & 12.8 & 13.9 & 16.3 & 0.63 & 0.116 \\
\hline trans-10, trans-12 CLA & $2.4^{\mathrm{c}}$ & $10.0^{\mathrm{a}}$ & $7.4^{\mathrm{b}}$ & 0.15 & 0.002 \\
\hline trans-11, trans-13 CLA & 15.4 & 18.9 & 15.3 & 0.52 & 0.061 \\
\hline trans- 12 , trans-14 CLA & $10.7^{\mathrm{b}}$ & $13.2^{\mathrm{a}}$ & $11.2^{\mathrm{b}}$ & 0.23 & 0.030 \\
\hline trans-13, trans-15 CLA & $1.1^{\mathrm{b}}$ & $1.2^{\mathrm{a}}$ & $0.8^{\mathrm{c}}$ & $<0.01$ & $<0.001$ \\
\hline
\end{tabular}

${ }^{\mathrm{a}-\mathrm{c}}$ Means within a row not sharing common superscripts differ $(P<0.05)$.

${ }^{1}$ Values represent means for d 5 of infusion for 3 cows.

${ }^{2}$ Treatments consisted of abomasal infusions of $60 \mathrm{~g}$ of ethanol/d (control); $60 \mathrm{~g}$ of ethanol/d and $6.0 \mathrm{~g} / \mathrm{d}$ of trans-10, cis-12 conjugated linoleic acid (CLA); or $60 \mathrm{~g}$ of ethanol/d and $247 \mathrm{~g} / \mathrm{d}$ of a mixture of $18: 1$ fatty acid methyl esters (T181) administered at 6-h intervals over a 5-d treatment period.

amounts of trans-10 18:1 were administered, infusions did not alter mammary lipogenesis (Lock et al., 2007). However, a recent evaluation suggested that the enrichment of trans-10 18:1 in milk from 0.47 to $1.11 \mathrm{~g} / 100$ $\mathrm{g}$ of fatty acids during postruminal infusions may have been too low for possible effects on mammary lipogenesis to be detected (Kadegowda et al., 2008). Therefore, the effects of administration of higher amounts of trans-10 18:1 at the abomasum as part of a mixture of 18:1 FAME on milk fat synthesis were evaluated in the present experiment.

The T181 supplement was prepared as a mixture of methyl esters to ensure that the supplement was liquid at room temperature, thus improving handling properties. Previous studies have shown that postruminal infusions of the known milk fat inhibitor trans-10, cis-12 CLA as a FFA or FAME results in comparable reductions in milk fat synthesis (de Veth et al., 2004). Rather than using a highly purified trans-10 18:1 preparation, a mixture of 18:1 FAME containing trans-10 and trans-11 as major isomers was used. During diet-induced MFD, increases in ruminal trans-10 18:1 outflow are also accompanied by elevated amounts of trans-11 18:1, trans-12 18:1, cis-11 18:1, and cis-12 18:1 reaching the duodenum (Piperova et al., 2002; Loor et al., 2004), indicating that the composition of the T181 treatment mimics the changes in postruminal 18:1 that occur during diet-induced MFD.

Postruminal infusion of $6.0 \mathrm{~g} / \mathrm{d}$ of trans-10, cis-12 CLA resulted in a $41.4 \%$ reduction in milk fat secretion, consistent with an expected decrease of between 35.8 and $39.2 \%$ based on relationships developed using data from several studies (de Veth et al., 2004; Shingfield and Griinari, 2007). Treatment T181 resulted in 21.3 and $19.5 \%$ reductions in milk fat content and yield, respectively. Decreases in milk fat were apparent within $48 \mathrm{~h}$ and continued until the end of the infusion period. Because the T181 treatment contained a mixture of 18:1 isomers, no direct cause and effect can be established, but strong inferences on the contribution of individual constituent fatty acids to the observed reductions in milk fat to treatment T181 supplement can be drawn based on earlier studies. Treatment T181 supplied $92.1 \mathrm{~g} / \mathrm{d}$ of trans-11 18:1, but there is clear evidence that this isomer is not involved in mammary lipogenesis in the bovine. Postruminal infusions of a 
mixture of FFA supplying between 12.5 and $41.4 \mathrm{~g} / \mathrm{d}$ trans-11 18:1 have been shown to have no effect on milk fat secretion (Griinari et al., 2000; Shingfield et al., 2007; Tyburczy et al., 2008). Incremental inclusion of sunflower oil in grass silage-based diets was shown to enhance trans-11 18:1 flow at the omasum from to 14.9 to $126 \mathrm{~g} / \mathrm{d}$, whereas milk fat output remained unchanged (Shingfield et al., 2008). Furthermore, supplementing grass hay-based diets with linseed oil resulted in a significant enrichment of trans-11 18:1 in milk fat from 1.21 to $7.49 \mathrm{~g} / 100 \mathrm{~g}$ of fatty acids - changes that were independent of alterations in milk fat synthesis (Roy et al., 2006).

Administration of the T181 supplement also supplied smaller quantities (g/d) of cis-9 18:1 (23.3), cis-10 18:1 (3.24), cis-11 18:1 (3.20), cis-12 18:1 (8.26), trans-8 18:1 (0.86), trans-9 18:1 (4.08), trans-12 18:1 (6.55), and trans-13 18:1 (1.46). Data from earlier experiments indicate that the amount of cis-9 18:1 supplied by treatment T181 would be expected to enhance or maintain rather than inhibit milk fat synthesis (Enjalbert et al., 1998; Romo et al., 2000; Drackley et al., 2007). Evidence from several studies also indicate that milk fat synthesis is not altered in response to postruminal infusions supplying 25.0 to $41.7 \mathrm{~g} / \mathrm{d}$ of trans -9 18:1 (Rindsig and Schultz, 1974; Tyburczy et al., 2008), $1.4 \mathrm{~g} / \mathrm{d}$ of cis-10 18:1 (Lock et al., 2007), 12.5 to 28.5 $\mathrm{g} / \mathrm{d}$ of trans-12 18:1 (Griinari et al., 2000; Shingfield et al., 2007) or $1.2 \mathrm{~g} / \mathrm{d}$ of trans-13 18:1, $12.4 \mathrm{~g} / \mathrm{d}$ of cis11 18:1, and $12.4 \mathrm{~g} / \mathrm{d}$ of cis-12 18:1 (Shingfield et al., 2007). An established lack of association of MFD with fatty acids supplied at similar or greater amounts than the T181 treatment point toward trans-10 18:1 as the most probable candidate responsible for the inhibitory effects on milk fat synthesis.

Abomasal infusion of trans-10 18:1 was shown to have no effect on milk fat synthesis in lactating cows (Lock et al., 2007), which is in direct contrast to an implied role of trans-10 18:1 for the responses to treatment T181 in this experiment. Infusion of the T181 treatment resulted in the uptake and incorporation of $39.5 \mathrm{~g} / \mathrm{d}$ of trans-10 18:1 into milk, which is about 6-fold greater than the $6.4 \mathrm{~g} / \mathrm{d}$ in previous investigations (Lock et al., 2007). A much greater effective dose at the mammary gland in the current experiment arises from both the larger amounts of trans-10 18:1 administered at the abomasum (92.1 vs. $42.6 \mathrm{~g} / \mathrm{d}$ ), and a more efficient transfer of this isomer into milk fat (40.5 vs. 15.0\%). Reductions in milk fat synthesis to trans-10, cis-12 CLA are dose-dependent (Baumgard et al., 2001; Peterson et al., 2002; de Veth et al., 2004), and it is probable that apparent discrepancies on the possible role of trans-10 18:1 in the regulation of mammary lipogenesis between studies are related to the availability of this isomer at the mammary gland, as would be implied based on a recent evaluation of the changes in milk fat composition during diet-induced MFD (Kadegowda et al., 2008).

Variations in the recovery of infused trans-10 18:1 in milk fat are difficult to reconcile. Postruminal infusions of partially hydrogenated vegetable oils (PHVO) demonstrated that apparent transfer of trans 18:1 from the abomasum into milk can vary between 27.9 and 45.1\% (Gaynor et al., 1994; Romo et al., 2000), whereas isomer-specific determinations indicate a mean transfer of trans-10 18:1 at the omasum or duodenum into milk of 32.1\% (Shingfield and Griinari, 2007). Apparent absorption of trans 18:1 between the duodenum and ileum is known to be less for diets containing hydrogenated tallow, and absorption of fatty acids with a melting point above body temperature can, under certain situations, be compromised due to reduced solubility in micelles (Glasser et al., 2008b). Efficient transfer of fatty acids from the small intestine into milk is dependent on the partitioning of a fatty acid into TAG during the assembly of chylomicrons and very low density lipoproteins in the intestinal epithelium (Christie, 1981). Studies on the fate of absorbed trans-10 18:1 are limited, but suggest preferential incorporation into plasma TAG and NEFA (Loor and Herbein, 2003; AbuGhazaleh et al., 2003) and comparable extraction across the mammary gland relative to trans-11 18:1 (Loor and Herbein, 2003), consistent with identical recoveries of these isomers in milk fat for treatment T181. In contrast, indirect comparisons of the effects of postruminal infusions of FFA preparations indicate that trans-9 18:1 and trans-11 18:1 are transferred efficiently from the abomasum into milk with a mean efficiency of 59.7 and $54.3 \%$, respectively (Tyburczy et al., 2008) compared with $15 \%$ for trans-10 18:1 (Lock et al., 2007) in cows fed comparable diets. Such differences may reflect the lower melting point of supplements enriched with trans-9 18:1 and trans-11 18:1 (42 to $46^{\circ} \mathrm{C}$; Tyburczy et al., 2008) compared with trans-10 18:1 (52 to $53^{\circ} \mathrm{C}$; Lock et al., 2007), or the warming of dissolved FFA preparations to $37^{\circ} \mathrm{C}$ immediately before infusion (Tyburczy et al., 2008).

Recovery of trans-11 18:1 on treatment T181 is comparable to previous estimates of $40 \%$ in response to $25 \mathrm{~g} / \mathrm{d}$ of an equimolar mixture of trans-11 18:1 and trans-12 18:1 (Griinari et al., 2000), is greater than the $28.6 \%$ based on postruminal infusion of FFA preparations supplying $29.4 \mathrm{~g} / \mathrm{d}$ of trans-11 18:1 (Shingfield et al., 2007), but less than recent values reported for greater purity FFA supplements providing $41.4 \mathrm{~g} / \mathrm{d}$ of trans-11 18:1 (Tyburczy et al., 2008). Extensive analysis of published data suggests that although most C18 fatty acids are apparently transferred from the duodenum into milk at a similar efficiency, there is considerable variation between experiments (Glasser et al., 2008a). 
It appears plausible that the fatty acid composition and melting point of lipid supplements, in addition to the overall supply of fatty acids in the small intestine may contribute to the variance in the efficiency of trans-10 18:1 transfer from the abomasum into milk. In this regard, it is notable that the melting point of the mixture of 18:1 FAME infused in this experiment $\left(18^{\circ} \mathrm{C}\right)$ is substantially lower than that of trans-10 18:1 in FFA form $\left(53^{\circ} \mathrm{C}\right.$; Shingfield and Griinari, 2007).

Reductions in milk fat output are known to be associated with increases in ruminal trans-10 18:1 outflow (Shingfield and Griinari, 2007) and milk fat trans-10 18:1 content (Loor et al., 2005; Shingfield and Griinari, 2007). Extrapolations from these reationships infer that the amount of trans-10 18:1 supplied by the T181 treatment could be expected to induce a $30.8 \%$ reduction in milk fat secretion, while the increases in milk trans-10 18:1 content to treatment T181 would be accompanied by 32.1 to $36.3 \%$ decreases in milk fat yield. However, associations do not establish a direct cause and effect, but also include the contribution due to increases in ruminal outflow of trans-10, cis-12 CLA, cis-10, trans-12 CLA, and trans-9, cis-11 CLA that also inhibit milk fat synthesis in the lactating cow (Baumgard et al., 2000; Sæb $\varnothing$ et al., 2005; Perfield et al., 2007). It therefore follows that if a role for trans-10 18:1 as a putative milk fat inhibitor were to hold true, the magnitude of reductions in milk fat yield directly attributable to this isomer on treatment T181 would be lower than predicted. Reductions in milk fat output to treatment T181 are equivalent to predicted decreases to postruminal infusions of 1.9 to $2.2 \mathrm{~g} / \mathrm{d}$ of trans-10, cis-12 CLA (de Veth et al., 2004; Shingfield and Griinari, 2007), indicating that potential antilipogenic effects attributable to trans-10 18:1 would be 40 to 50 fold lower than trans-10, cis-12 CLA.

Infusion of the CLA treatment resulted in a reduction in the secretion of both short and long chain fatty acids, consistent with trans-10, cis-12 CLA reducing mammary abundance of mRNA encoding for key lipogenic enzymes involved in fatty acid uptake and transport, de novo fatty acid synthesis, and TAG synthesis (Baumgard et al., 2002; Harvatine and Bauman, 2006). In contrast, reductions in milk fat yield to treatment T181 were confined to decreases in the secretion of fatty acids synthesized de novo. Previous studies have also demonstrated that decreases in milk fat output to postruminal infusions of PHVO are due to the effects on de novo fatty acid synthesis (Gaynor et al., 1994; Romo et al., 2000). Milk fat composition responses to postruminal infusions of trans 18:1 are often variable and known to be isomer dependent. Administration of trans-9 18:1 (Rindsig and Schultz, 1974) and trans-10 18:1 (Lock et al., 2007) had no effect on milk fat 12:0,
14:0, and 16:0 content, whereas a mixture of fatty acids enriched in trans-11 18:1 and trans-12 18:1 decreased concentrations of fatty acids synthesized de novo, which was accompanied by an increase in the secretion of preformed fatty acids (Shingfield et al., 2007). Possible mechanisms underlying the response to treatment T181 remain unclear, but it has been postulated that reductions in milk fat to postruminal infusions of PHVO are potentially mediated via an inhibition of mammary acyl transferase activity and lowered synthesis of milk fat TAG (Gaynor et al., 1994; Romo et al., 2000).

Treatment T181 supplied $92.1 \mathrm{~g} / \mathrm{d}$ of trans-11 18:1 and enhanced milk fat trans-11 18:1 and CLA concentrations. Concentration ratios of product versus product plus substrate for $\Delta^{9}$-desaturase indicate that $27.5 \%$ of trans-11 18:1 administered was converted to cis-9, trans-11 CLA, consistent with previous estimates of 24.6 to $28.9 \%$ (Mosley et al., 2006; Shingfield et al., 2007; Tyburczy et al., 2008). Despite differences between individual animals, breeds, and experimental approaches, a close agreement in the estimates of endogenous cis-9, trans-11 CLA synthesis provides further support that the action of $\Delta^{9}$-desaturase on trans-11 18:1 to cis-9, trans-11 CLA is essentially constant under most conditions in the lactating cow (Griinari and Bauman, 1999; Shingfield et al., 2007; Glasser et al., 2008a).

Reductions in milk fat in response to postruminal CLA infusion were also accompanied by decreases in milk fat cis-9 10:1/10:0 and cis-9 12:1/12:0 concentrations ratios that serve as a proxy for $\Delta^{9}$-desaturase (Bauman and Davis, 1974; Bernard et al., 2008), consistent with trans-10, cis-12 CLA downregulating $\Delta^{9}$-desaturase gene expression (Baumgard et al., 2002; Palmquist et al., 2005). Decreases in mammary lipogenesis to abomasal infusion of high doses of mixed CLA isomers or relatively pure trans-10, cis-12 CLA preparations are also typically associated with a reduction in milk fat cis-9 14:1/14:0, cis-9 16:1/16:0 and cis-9 18:1/18:0 concentration ratios (Shingfield and Griinari, 2007). However, changes in these specific substrateproduct indices in milk in response to CLA infusion in this experiment were not significant, a finding which is both unexpected and difficult to reconcile because the cis-9 14:1/14:0 ratio in milk is thought to reflect mammary $\Delta^{9}$-desaturase activity (Bernard et al., 2008). Administration of treatment T181 had no significant effect on milk fat desaturase indices. In vitro studies have shown that incubations with trans-10 18:1 and trans-11 18:1 had no effect on $\Delta^{9}$-desaturase activity of murine hepatic microsomes (Park et al., 2000).

In conclusion, abomasal infusion of a mixture of 18:1 isomers containing trans-10 and trans-11 as major components decreased milk fat content and yield. Because of the use of a mixture of FAME it was not possible to 
establish a direct cause and effect, but considerations of the amount and established association of infused fatty acids with MFD implicated trans-10 18:1 as the isomer responsible. Further studies are required using relatively pure preparations of high availability in the small intestine to allow unambiguous conclusions to be drawn on the role of trans-10 18:1 on mammary lipogenesis during diet-induced MFD.

\section{ACKNOWLEDGMENTS}

The technical assistance of MTT staff in the metabolism unit for diligent care of experimental animals and sample collection, and the contributions of Minna Aalto and Piia Kairenius at MTT to sample lipid analysis are gratefully acknowledged and appreciated.

\section{REFERENCES}

AbuGhazaleh, A. A., D. J. Schingoethe, A. R. Hippen, and K. F. Kalscheur. 2003. Conjugated linoleic acid and vaccenic acid in rumen, plasma and milk of cows fed fish oil and fats differing in saturation of 18 carbon fatty acid profiles. J. Dairy Sci. 86:36483660.

Bauman, D. E., and C. L. Davis. 1974. Biosynthesis of milk fat. Pages 31-75 in Lactation: A Comprehensive Treatise. Vol. 2. B.L. Larson and V.R. Smith, ed. Academic Press, London, UK.

Bauman, D. E., and J. M. Griinari. 2001. Regulation and nutritional manipulation of milk fat: Low-fat milk syndrome. Livest. Prod. Sci. 70:15-29.

Bauman, D. E., and J. M. Griinari. 2003. Nutritional regulation of milk fat synthesis. Annu. Rev. Nutr. 23:203-227.

Baumgard, L. H., B. A. Corl, D. A. Dwyer, A. Saebø, and D. E. Bauman. 2000. Identification of the conjugated linoleic acid isomer that inhibits milk fat synthesis. Am. J. Physiol. 278:R179-R184.

Baumgard, L. H., E. Matitashvili, B. A. Corl, D. A. Dwyer, and D. E. Bauman. 2002. Trans-10, cis-12 conjugated linoleic acid decreases lipogenic rates and expression of genes involved in milk lipid synthesis in dairy cows. J. Dairy Sci. 85:2155-2163.

Baumgard, L. H., J. K. Sangster, and D. E. Bauman. 2001. Milk fat synthesis in dairy cows is progressively reduced by increasing supplemental amounts of trans-10, cis-12 conjugated linoleic acid (CLA). J. Nutr. 131:1764-1769.

Bernard, L., C. Leroux, and Y. Chilliard. 2008. Expression and nutritional regulation of lipogenic genes in the ruminant lactating mammary gland. Pages 67-108 in Bioactive Components of Milk. Advances in Experimental Medicine and Biology. Vol. 606. Z. Bösze, ed. Springer, New York, NY.

Chilliard, Y., and A. Ferlay. 2004. Dietary lipids and forages interactions on cow and goat milk fatty acid composition and sensory properties. Reprod. Nutr. Dev. 44:467-492.

Christie, W. W. 1981. The effect of diet and other factors on the lipid composition of ruminant tissues and milk. Pages 193-226 in Lipid Metabolism in Ruminant Animals. W.W. Christie, ed. Pergamon Press, Oxford, UK.

Christie, W. W. 1982. A simple procedure for rapid transmethylation of glycerolipids and cholesteryl esters. J. Lipid Res. 23:10721075 .

Craske, J. D., and C. D. Bannon. 1988. Letter to the editor. J. Am. Oil Chem. Soc. 65:1190-1191.

Davis, C. L., and R. E. Brown. 1970. Low-fat milk syndrome. Pages 545-565 in Physiology of Digestion and Metabolism in the Ruminant. A.T. Phillipson, ed. Oriel Press, Newcastle upon Tyne, UK.
Delmonte, P., A. Kataok, B. A. Corl, D. E. Bauman, and M. P Yurawecz. 2005. Relative retention order of all isomers of cis/trans conjugated linoleic acid FAME from the 6,8- to 13,15-positions using silver ion HPLC with two elution systems. Lipids 40:509514.

de Veth, M. J., J. M. Griinari, A. M. Pfeiffer, and D. E. Bauman. 2004. Effect of CLA on milk fat synthesis in dairy cows: Comparison of inhibition by methyl esters and free fatty acids, and relationships among studies. Lipids 39:365-372.

Drackley, J. K., T. R. Overton, G. Ortiz-Gonzalez, A. D. Beaulieu, D. M. Barbano, J. M. Lynch, and E. G. Perkins. 2007. Responses to increasing amounts of high-oleic sunflower fatty acids infused into the abomasum of lactating dairy cows. J. Dairy Sci. 90:51655175

Enjalbert, F., M.-C. Nicot, C. Bayourthe, and R. Moncoulon. 1998. Duodenal infusions of palmitic, stearic or oleic acids differently affect mammary gland metabolism of fatty acids in lactating dairy cows. J. Nutr. 128:1525-1532.

Gaynor, P. J., R. A. Erdman, B. B. Teter, J. Sampugna, A. V. Capuco, D. R. Waldo, and M. Hamosh. 1994. Milk fat yield and composition during abomasal infusion of cis or trans octadecenoates in Holstein cows. J. Dairy Sci. 77:157-165.

Glasser, F., A. Ferlay, M. Doreau, P. Schmidely, D. Sauvant, and Y. Chilliard. 2008a. Long-chain fatty acid metabolism in dairy cows: A meta-analysis of milk fatty acid yield in relation to duodenal flows and de novo synthesis. J. Dairy Sci. 91:2771-2785.

Glasser, F., P. Schmidely, D. Sauvant, and M. Doreau. 2008b. Digestion of fatty acids in ruminants: A meta-analysis of flows and variation factors: 2. C18 fatty acids. Animal 2:691-704.

Griinari, J. M., and D. E. Bauman. 1999. Biosynthesis of conjugated linoleic acid and its incorporation into meat and milk in ruminants. Pages 180-200 in Advances in Conjugated Linoleic Acid Research. Vol. 1. M. P. Yurawecz, M. M. Mossoba, J. K. G. Kramer, M. W. Pariza, and G. J. Nelson, ed. AOCS Press, Champaign, IL.

Griinari, J. M., B. A. Corl, S. H. Lacy, P. Y. Chouinard, K. V. V. Nurmela, and D. E. Bauman. 2000. Conjugated linoleic acid is synthesized endogenously in lactating dairy cows by $\Delta 9$-desaturase. J. Nutr. 130:2285-2291.

Griinari, J. M., D. A. Dwyer, M. A. McGuire, D. E. Bauman, D. L. Palmquist, and K. V. V. Nurmela. 1998. Trans-octadecenoic acids and milk fat depression in lactating dairy cows. J. Dairy Sci. $81: 1251-1261$.

Harvatine, K. J., and D. E. Bauman. 2006. SREBP1 and thyroid hormone responsive spot 14 (S14) are involved in the regulation of bovine mammary lipid synthesis during diet-induced milk fat depression and treatment with CLA. J. Nutr. 136:2468-2474.

IDF. 1987. Milk-Determination of fat content: Gravimetric method (Röse-Gottlieb reference method), International Standard IDF-1C; and Cream-Determination of fat content: Gravimetric method (Röse-Gottlieb reference method), International Standard IDF16C. International Dairy Federation, Brussels, Belgium.

Kadegowda, A. K. G., L. S. Piperova, and R. A. Erdman. 2008 Principle component and multivariate analysis of milk long-chain fatty acid composition during diet-induced milk fat depression. J. Dairy Sci. 91:749-759.

Lock, A. L., and K. J. Shingfield. 2004. Optimising milk composition. Pages 107-188 in Dairying - Using Science to Meet Consumers Needs. E. Kebreab, J. Mills, and D.E. Beever, ed. Br. Soc. Anim. Sci. Publ. 29. Nottingham University Press, Loughborough, UK.

Lock, A. L., C. Tyburczy, D. A. Dwyer, K. J. Harvatine, F. Destaillats, Z. Mouloungui, L. Candy, and D. E. Bauman. 2007. Trans-10 octadecenoic acid does not reduce milk fat synthesis in dairy cows. J. Nutr. 137:71-76.

Loor, J. J., A. Ferlay, A. Ollier, M. Doreau, and Y. Chilliard. 2005. Relationship among trans and conjugated fatty acids and bovine milk fat yield due to dietary concentrate and linseed oil. J. Dairy Sci. 88:726-740.

Loor, J. J., and J. H. Herbein. 2003. Reduced de novo synthesis and desaturation due to exogenous trans10, cis12-CLA in cows fed oleic or linoleic oil. J. Dairy Sci. 86:1354-1369. 
Loor, J. J., K. Ueda, A. Ferlay, Y. Chilliard, and M. Doreau. 2004. Biohydrogenation, duodenal flow, and intestinal digestibility of trans-fatty acids and conjugated linoleic acids in response to dietary forage:concentrate ratio and linseed oil in dairy cows. J. Dairy Sci. 87:2472-2485.

Mosley, E. E., B. Shafii, P. J. Moate, and M. A. McGuire. 2006. Cis9, trans-11 conjugated linoleic acid is synthesized directly from vaccenic acid in lactating dairy cattle. J. Nutr. 136:570-575.

MTT Agrifood Research Finland. 2006. Rehutaulukot ja ruokintasuositukset [Feed tables and feeding recommendations]. http://www.mtt.fi/mtts/pdf/mtts106.pdf Accessed February 14, 2006.

Palmquist, D. L., A. D. Beaulieu, and D. M. Barbano. 1993. Feed and animal factors influencing milk fat composition. J. Dairy Sci. 76:1753-1771.

Palmquist, D. L., A. L. Lock, K. J. Shingfield, and D. E. Bauman. 2005. Biosynthesis of conjugated linoleic acid in ruminants and humans. Pages 179-217 in Advances in Food and Nutrition Research. Vol. 50. S.-L. Taylor, ed. Elsevier Academic Press, San Diego, CA.

Park, Y., J. M. Storkson, J. M. Ntambi, M. E. Cook, C. J. Sih, and M. W. Pariza. 2000. Inhibition of hepatic stearoyl-CoA desaturase activity by trans-10, cis-12 conjugated linoleic acid and its derivatives. Biochim. Biophys. Acta 1486:285-292.

Perfield, J. W. II, A. L. Lock, J. M. Griinari, A. Sæbø, P. Delmonte, D. A. Dwyer, and D. E. Bauman. 2007. Trans-9, cis-11 conjugated linoleic acid (CLA) reduces milk fat synthesis in lactating dairy cows. J. Dairy Sci. 90:2211-2218.

Peterson, D. G., L. H. Baumgard, and D. E. Bauman. 2002. Milk fat response to low doses of trans-10, cis-12 conjugated linoleic acid (CLA). J. Dairy Sci. 85:1764-1766.

Piperova, L. S., U. Moallem, B. B. Teter, J. Sampugna, M. P. Yurawecz, K. M. Morehouse, D. Luchini, and R. A. Erdman. 2004. Changes in milk fat in response to dietary supplementation with calcium salts of trans-18:1 or conjugated linoleic fatty acids in lactating dairy cows. J. Dairy Sci. 87:3836-3844.

Piperova, L. S., L. Sampugna, B. B. Teter, K. F. Kalscheur, M. P. Yurawecz, Y. Ku, K. M. Morehouse, and R. A. Erdman. 2002. Duodenal and milk trans octadecanoic acid and conjugated linoleic acid (CLA) isomers indicate that postabsorptive synthesis is the predominant source of cis-9-containing CLA in lactating dairy cows. J. Nutr. 132:1235-1241.

Piperova, L. S., B. B. Teter, I. Bruckental, J. Sampugna, S. E. Mills, M. P. Yurawecz, J. Fritsche, K. Ku, and R. A. Erdman. 2000. Mammary lipogenic enzyme activity, trans fatty acids and conjugated linoleic acids are altered in lactating dairy cows fed a milk fat-depressing diet. J. Nutr. 130:2568-2574.

Rindsig, R. B., and L. H. Schultz. 1974. Effects of abomasal infusions of safflower oil or elaidic acid on blood lipids and milk fat in dairy cows. J. Dairy Sci. 57:1459-1466.

Romo, G. A., R. A. Erdman, B. B. Teter, J. Sampugna, and D. P. Casper. 2000. Milk composition and apparent digestibilities of dietary fatty acids in lactating dairy cows abomasally infused with cis or trans fatty acids. J. Dairy Sci. 83:2609-2619.

Roy, A., A. Ferlay, K. J. Shingfield, and Y. Chilliard. 2006. Examination of the persistency of milk fatty acid composition responses to plant oils in cows fed different basal diets, with particular emphasis on trans-C18:1 fatty acids and isomers of conjugated linoleic acid. Anim. Sci. 82:479-492.

Sæbø, A., P. Sæbø, J. M. Griinari, and K. J. Shingfield. 2005. Effect of abomasal infusion of geometric isomers of 10,12 conjugated linoleic acid on milk fat synthesis in dairy cows. Lipids 40:823-832.

Shingfield, K. J., S. Ahvenjärvi, V. Toivonen, A. Ärölä, K. V. V. Nurmela, P. Huhtanen, and J. M. Griinari. 2003. Effect of fish oil on biohydrogenation of fatty acids and milk fatty acid content in cows. Anim. Sci. 77:165-179.

Shingfield, K. J., S. Ahvenjärvi, V. Toivonen, A. Vanhatalo, and P. Huhtanen. 2007. Transfer of absorbed cis-9, trans-11 conjugated linoleic acid into milk is biologically more efficient than endogenous synthesis from absorbed vaccenic acid in lactating cows. J. Nutr. 137:1154-1160.

Shingfield, K. J., S. Ahvenjärvi, V. Toivonen, A. Vanhatalo, P. Huhtanen, and J. M. Griinari. 2008. Effect of incremental levels of sunflower-seed oil in the diet on ruminal lipid metabolism in lactating cows. Br. J. Nutr. 99:971-983.

Shingfield, K. J., and J. M. Griinari. 2007. Role of biohydrogenation intermediates in milk fat depression. Eur. J. Lipid Sci. Technol. 109:799-816

Shingfield, K. J., S. Jaakkola, and P. Huhtanen. 2001. Effects of level of nitrogen fertiliser application and various nitrogenous supplements on milk production and nitrogen utilization of dairy cows fed grass silage-based diets. Anim. Sci. 73:541-554.

Shingfield, K. J., C. K. Reynolds, G. Hervás, J. M. Griinari, A. S. Grandison, and D. E. Beever. 2006. Examination of the persistency of milk fatty acid composition responses to fish oil and sunflower oil in the diet of dairy cows. J. Dairy Sci. 89:714-732.

Shingfield, K. J., C. K. Reynolds, B. Lupoli, V. Toivonen, M. P. Yurawecz, P. Delmonte, J. M. Griinari, A. S. Grandison, and D. E. Beever. 2005. Effect of forage type and proportion of concentrate in the diet on milk fatty acid composition in cows fed sunflower oil and fish oil. Anim. Sci. 80:225-238.

Tyburczy, C., A. L. Lock, D. A. Dwyer, F. Destaillats, Z. Mouloungui, L. Candy, and D. E. Bauman. 2008. Uptake and utilization of trans octadecenoic acids in lactating dairy cows. J. Dairy Sci 91:3850-3861.

Ulberth, F., R. G. Gabernig, and F. Schrammel. 1999. Flame-ionization detector response to methyl, ethyl, propyl, and butyl esters of fatty acids. J. Am. Oil Chem. Soc. 76:263-266.

Wallace, R. J., N. McKain, K. J. Shingfield, and E. Devillard. 2007. Isomers of conjugated linoleic acids are synthesized via different mechanisms in ruminal digesta and bacteria. J. Lipid Res. $48: 2247-2254$ 